\title{
Pengaruh Komik Lipat Sederhana Terhadap Hasil Belajar Fisika di MTs Nurul Ishlah Gegelang
}

\author{
${ }^{1}$ Linda Sekar Utami, ${ }^{2}$ Johri Sabaryati, ${ }^{3} \mathrm{Ni}$ Wayan Sri Darmayanti, ${ }^{4}$ Eka Fitriani \\ 1.2 Pendidikan Fisika, Universitas Muhammadiyah Mataram, Indonesia \\ ${ }^{3}$ STKIP Suar Bangli Bali, Indonesia \\ ${ }^{4}$ TK IT Abata Lombok, Indonesia \\ lindasekarutami@gmail.com, Joyafarashy@gmail.com, wyndarmayanti@gmail.com, \\ ekaabata88@gmail.com
}

\begin{tabular}{|c|c|}
\hline ARTICLE & IFO \\
\hline Article $\mathrm{Hi}$ & story: \\
\hline Received & : 12-03-2020 \\
\hline Revised & : 27-05-2020 \\
\hline Accepted & : 28-05-2020 \\
\hline Online & : 30-05-2020 \\
\hline Keyworc & \\
\hline $\begin{array}{l}\text { Komik } \\
\text { Belajar }\end{array}$ & Lipat; Hasil \\
\hline
\end{tabular}

\begin{abstract}
Abstract: This study aims to find out the results of physics learning between students who follow the learning with simple folding comic Physics with students who follow conventional learning in grade IX B students at MTs Nurul Ishlah Gegelang. This type of research is included in experimental quasi design research. The population used is all grade IX students in MTS Nurul Ishlah Gegelang. In this study, two classes were taken as a sample of research divided into experimental classes and control classes. obtained samples are class IX B MTs Nurul Ishlah Gegelang as an experimental group and class IX A MTS Nurul Ishlah Gegelang as a control group. Research data in the form of physics learning results in the cognitive sphere was collected using a test of learning results, this research using the design of Pretest-Posstes. The collected data were then analyzed using t-related tests to determine significant differences in learning outcomes between the two sample classes. Based on the results of the study obtained the initial ability of students for both groups is homogeneous shown by Fhitung < Ftabel $(1.07<2.14)$ and the differences between the two groups are insignificant on the subject of energy changes with units and the final ability test ruler shown by thitung $>$ ttabel (3,134 > 2,005), so Ha was accepted.
\end{abstract}

Abstrak: Penelitian ini bertujuan untuk mengetahui pngaruh hasil belajar fisika antara siswa yang mengikuti pembelajaran dengan komik lipat sederhana Fisika dengan siswa yang mengikuti pembelajaran konvensional pada siswa kelas kelas IX B di MTs Nurul Ishlah Gegelang. Jenis penelitian ini termasuk dalam penelitian quasi eksperimental design. Populasi yang dipergunakan adalah seluruh siswa kelas IX di MTs Nurul Ishlah Gegelang. Pada penelitian ini diambil dua kelas sebagai sampel penelitian yang terbagi dalam kelas eksperimen dan kelas kontrol. diperoleh sampel yaitu kelas IX B MTs Nurul Ishlah Gegelang sebagai kelompok eksperimen dan kelas IX A MTs Nurul Ishlah Gegelang sebagai kelompok kontrol. Data penelitian berupa hasil belajar fisika pada ranah kognitif dikumpulkan menggunakan tes hasil belajar, Penelitian ini menggunakan desain Pretest-Posstes. Data yang terkumpul selanjutnya dianalisis menggunakan uji-t related untuk mengetahui perbedaan hasil belajar yang signifikan antara kedua kelas sampel. Berdasarkan hasil penelitian diperoleh kemampuan awal siswa untuuk kedua kelompok adalah homogen yang ditunjukkan dengan Fhitung < Ftabel $(1,07<2,14)$ serta perbedaan yang dimiliki antara kedua kelompok tidak signifikan pada pokok bahasan perubahan energi dengan satuan dan pengkuran tes kemampuan akhir yang ditunjukkan dengan thitung $>$ ttabel $(3,134>2,005)$, sehingga Ha diterima. 


\section{A. LATAR BELAKANG}

Kualitas dan kuantitas pendidikan sampai saat ini masih tetap merupakan masalah yang paling menonjol dalam setiap usaha pembaharuan sistem pendidikan nasional (Utami and Darmayanti 2019)(Nurfiati, Vera Mandailina, Mahsup, Syaharuddin 2020). Usaha tersebut meliputi pembaharuan kurikulum dan proses belajar mengajar, peningkatan kualitas pengajaran, kualitas guru, pengadaan sarana dan prasarana belajar, serta usaha lainnya (Mikraj, Utami, and Zulkarnain 2019)(Mahsup and Anwar 2020). Seorang guru dituntut untuk mengadakan pembaharuan karena ilmu pengetahuan bersifat dinamis (Mukminah, Eka Fitriani, Mahsup 2019)(Darmayanti and Utami 2018). Guru harus memiliki kemampuan mengembangkan metode pengajaran sedemikian rupa sehingga tujuan pembelajaran yang diharapkan dalam Garis-Garis Besar Program Pengajaran (GBPP) dapat dicapai dengan baik (Marga, Isnaini, and Utami 2018)(Eka Fitriani 2018). Dalam suatu proses belajar- mengajar, ada beberapa unsur yang sangat penting diantaranya yaitu metode mengajar dan media pembelajaran (Ibrahim, Utami, and Darmayanti 2018)(Muhardini et al. 2020). Pemilihan salah satu metode mengajar tertentu akan mempengaruhi jenis media pembelajaran (Mahsup 2011)(Adriyanto, Dewi Pramita, Abdillah, Syaharuddin, Mahsup 2019). Penggunaan metode dan media pengajaran yang tepat diharapkan mampu membangkitkan semangat belajar siswa dan mampu membuat siswa berperan aktif sehingga berpengaruh terhadap hasil belajar siswa (Hamzah, Utami, and Zulkarnain 2019)(Mahsup 2018).

Kegiatan belajar-mengajar merupakan kunci pokok terlahirnya hasil belajar yang melibatkan guru (pengajar) dan peserta didik (Ferniawan, Sabaryati, and Utami 2020)(Mandailina and Mahsup 2018). Di dalam kegiatan belajar-mengajar tampaknya guru merupakan faktor dominan yang menentukan kualitasnya(Rahmatin et al. 2019)(Setyowati, Kristin, and Anugraheni 2018). Dalam proses belajar-mengajar peserta didik merupakan "bahan mentah" yang akan diolah di dalam lembaga pendidikan yang nantinya akan berubah menjadi "hasil olahan"(Murtiah 2018)(Aribawati, Kristin, and ... 2018)(Kabunggul et al. 2020). Sedangkan guru mempunyai tugas untuk memotivasi, membimbing dan memberi fasilitas belajar bagi siswa untuk mencapai tujuan (Mahsup and Anwar 2020)(Utami 2018).

Berdasarkan hasil observasi terhadap proses pembelajaran mata pelajaran IPA Fisika siswa kelas IX MTs. Nurul Ishlah, diperoleh kesimpulan bahwa kurang pemahaman siswa terhadap konsep materi yang diajarkan oleh guru mata pelajaran karena selama proses belajar mengajar berlangsung banyak siswa yang tidak memperhatikan apa yang dijelaskan oleh guru mata pelajaran atau hanya beberapa siswa yang memperhatikan. Siswa juga kurang aktif bertanya tentang hal-hal yang kurang dimengerti atau kurang aktif dalam proses belajar-mengajar. Dalam penelitian yang telah dilakukan oleh Maya (2007: 35) menyatakan bahwa media komik dalam pembelajaran fisika dapat memeberikan kontribusi yang cukup berarti dalam meningkatkan penguasaan konsep siswa.

Penelitian ini bertujuan untuk mengetahui pngaruh hasil belajar IPA fisika antara siswa yang mengikuti pembelajaran dengan komik lipat sederhana IPA Fisika dengan 
siswa yang mengikuti pembelajaran konvensional pada siswa kelas kelas IX B di MTs Nurul Ishlah Gegelang.

\section{B. METODE PENELITIAN}

Penelitian ini termasuk dalam penelitian True Eksperimental Design, karena dalam penelitian ini, peneliti dapat mengontrol semua variabel luar yang mempengaruhi jalannya eksperimen. Dengan demikian validitas internal (kualitas pelaksanaan rancangan penelitian) dapat menjadi tinggi (Sugiyono 2013)(Arikunto 2019). Waktu penelitian ini dimulai pada bulan Mei-Juni 2015 dan dilaksanakan di MTs Nurul Ishlah Gegelang. Populasi penelitian ini adalah seluruh siswa kelas IX MTs Hidayatullah Mataram tahun yang terdiri dua kelas, yaitu kelasIXA dan kelas IX B. Sampel dalam penelitian ini ditentukan kelas IX B sebagai kelas eksperimen yang akan mendapatkan perlakuan dengan memberi komik lipat sederhana IPA Fisika dan kelas IX A sebagai kelas kontrol yang mendapatkan perlakuan dengan metode ceramah.

Variabel dalam penelitian ini terdiri dari dua variabel bebas (independen) dan variabel terikat (dependen). Variabel bebas dalam penelitian ini adalah model pembelajaran dengan memberikan media komik lipat dan metode ceramah, sedangkan variabel terikat dalam penelitian ini adalah hasil belajar siswa. Instrumen yang digunakan dalam penelitian ini adalah tes dalam bentuk pilihan ganda (obyektif) yang dibuat oleh peneliti. Analisis Data yang digunakan dalam penelitian ini adalah Homogenitas Sampel, Normalitas Data dan Uji Hipotesis

\section{HASIL DAN PEMBAHASAN}

\section{1) Deskripsi Data}

Penelitian eksperimen ini telah dilaksanakan di MTs Nurul Ishlah Gegelang pada kelas IX B sebagai kelas eksperimen yang berjumlah 20 orang dan kelas IX A sebagai kelas kontrol yang berjumlah 21 orang. Penelitian dilakukan pada 4 kali pertemuan untuk masing-masing kelas sampel, dengan rincian dua kali pertemuan dalam 2 jam pelajaran untuk pretes dan posttes instrument soal. Adapun data yang diperoleh dalam penelitian ini, yaitu data penelitian kuantitatif, data kuantitatif diperoleh dari tes hasil belajar siswa menggunakan instrument soal.

Tabel 1. Deskripsi Data Hasil Pretest dan Posttes .

\begin{tabular}{lcccc}
\hline \multicolumn{1}{c}{ Deskripsi } & \multicolumn{2}{c}{ Kel. Eksperimen (IX B) } & \multicolumn{2}{c}{ Kel.Kontrol (IX A) } \\
& \multicolumn{2}{c}{$\mathbf{N = \mathbf { 2 0 }}$} & \multicolumn{2}{c}{ N = 1 } \\
\cline { 2 - 5 } & Pretest & 79,50 & 36,90 & 71,90 \\
Rata-rata $(\bar{x})$ & 36,25 & 95 & 55 & 90 \\
Skor maksimum & 55 & 60 & 20 & 50 \\
Skor minimum & 20 & $90 \%$ & $0 \%$ & $76,19 \%$ \\
Ketuntasan & $0 \%$ & & & \\
\hline
\end{tabular}

\section{2) Hasil Uji Instrument}

Sebelum tes diberikan kepada kelas eksperimen dan kelas kontrol, terlebih dahulu dilakukan uji validitas terhadap soal yang akan diujikan pada kelas yang sudah menerima pembelajaran dengan pokok bahasan Perubahan Energi untuk mengetahui apakah soal-soal tersebut layak untuk digunakan dalam penelitian. Dari hasil uji coba instrumen yang dilakukan pada kelas X MA NW Lingsar dengan jumlah siswa sebanyak 22 siswa, soal pretes dan posttes ang diuji validasi masing-masing sejumlah 30 butir soal dan yang valid pada pretes dan posttes masing-masing 20 butir soal. Untuk $\mathrm{N}=22$ dengan 
taraf signifikan $5 \%$, maka $r_{\text {tabel }}=0,423$ sehingga dapat ditentukan valid tidaknya soal tersebut.

Uji reliabilitas dilakukan pada 30 soal pretest dan posttest dengan menggunakan rumus pembelahan awal-akhir diperoleh nilai $\mathrm{r}_{11}$ pada pretest 0,91 dan pada posttest sebesar 0,88 sedangkan nilai $\mathrm{r}_{\text {tabel }}$ untuk taraf signifikan $5 \%$ dengan $\mathrm{N}=22$ sehingga diperoleh nilai 0,423 . Oleh karena itu $r_{\text {hitung }}$ lebih besar dari pada $r_{\text {tabel }}(0,91>0,423)$ dan pada posstest $(0,88>0,423)$. Maka instrumen penelitian ini memiliki tingkat reabilitas yang sangat kuat/tinggi. Uji tingkat kesukaran soal dimaksudkan untuk mengetahui tingkat perbedaan soal yang diberikan kepada siswa, berdasarkan hasil uji tingkat kesukaran soal yang diketahui bahwa soal yang berkriteria sukar tidak ada karena berada pada rentang $0,00-0,30$, soal yang berkriteria sedang sebanyak 29 soal karena berada pada rentang 0,30-0,70 dan soal yang berkriteria mudah sebanyak 1 soal.

Berdasarkan hasil uji daya beda soal, maka bahwa yang memiliki daya beda jelek pada soal prettes sebanyak 12 soal karena berada pada rentang 0,00-0,20 , daya beda cukup 14 soal karena berada pada rentang 0,21- 0,40, daya beda baik 3 soal karena berada pada rentang $0,41-0,70$, dan tidak ada soal yang memiliki daya beda baik sekali. Sedangkan pada soal posttest soal yang memiliki daya beda jelek sebanyak 8 soal karena berada pada rentang $0,00-0,20$, daya beda cukup sebanyak 20 soal karena berada pada rentang 0,21-0,40, daya beda baik 2 soal karena berada pada rentang 0,41-0,70.

Tabel 2. Rangkuman Uji Instrumen

\begin{tabular}{ll}
\hline Jenis uji & Jenis intrumen \\
\cline { 2 - 2 } Uji validasi & Soal \\
& Soal: \\
& -pretest: 30 \\
& -valid: 21 , invalid 9 \\
& -posttes: 22 , invalid: 8 \\
Uji reabilitas & Reabel \\
Uji taraf kesukaran & -pretest: sedang: 29 \\
& Mudah:1 \\
& -posttest: sedang: 28 \\
& Mudah: 2 \\
Uji Daya Beda & -pretest: jelek: 4, cukup: 14, baik: 11, baik sekali: 1 \\
& -posstest: jelek: 8 , cukup 20, baik: 2 \\
\hline
\end{tabular}

Keterangan : $\mathrm{N}=22$, taraf signifikan $=5 \%$, $\mathrm{r}$ tabel $=0,423$

\section{3) Analisis Data Hasil Penelitian}

Pretest atau atau tes kemampuan awal untuk instrumen berupa soal-soal materi Energi dilakukan pada kedua sampel (kelas eksperimen dan kelas kontrol). Hasil pretest tersebut dapat dilihat pada tabel dibawah ini.

Tabel 3. Data Hasil Uji Kemampuan Awal (Pretest) Siswa

\begin{tabular}{lcccc}
\hline \multicolumn{1}{c}{ Kelas } & Jumlah siswa & Nilai tertingi & Nilai terendah & Rerata \\
\hline Eksperimen & 20 & 55 & 20 & 36,25 \\
Kontrol & 21 & 55 & 20 & 36,90 \\
\hline
\end{tabular}

Tes akhir (posttest) juga diberikan kepada kedua sampel dengan menggunakan instrumen soal-soal Energi. Adapun hasil posttest yan diperoleh untuk kelas eksperimen dan kelas kontrol adalah sebagai berikut:

Tabel 4. Data Hasil Uji Kemampuan (Posttest) Siswa

\begin{tabular}{lllll}
\hline Kelas & Jumlah siswa & Nilai tertingi & Nilai terendah & Rerata \\
\hline
\end{tabular}




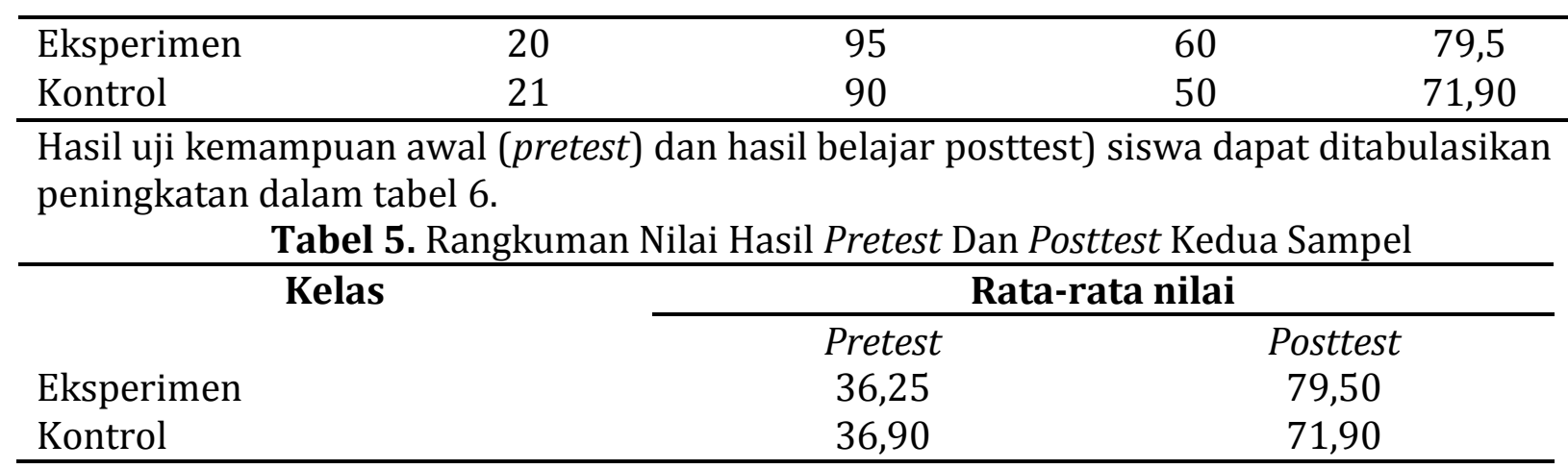

Berdasarkan hasil perhitungan rata-rata skor/nilai pretest dan posttest kedua kelas sampel terhadap peningkatan hasil belajar dari sebelum dan sesudah sampel diberi perlakuan. Peningkatan tersebut dapat dilihat pada grafik 1 peningkatan nilai kemampuan awal siswa (pre-test) dan hasil belajar (post-test) sebagai berikut:

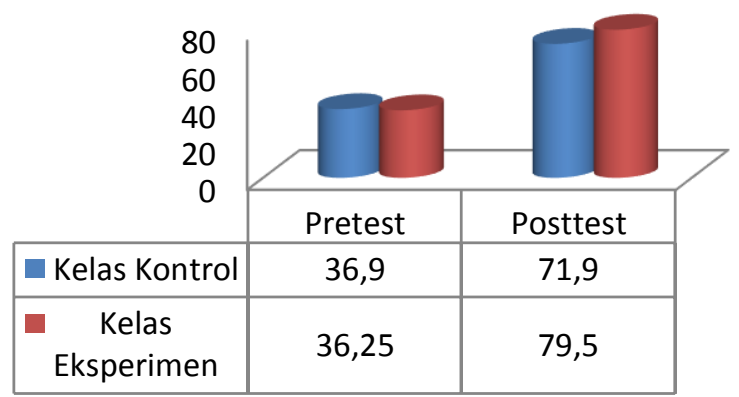

\section{4) Analis Data}

Gambar 1 Grafik Rata-Rata Hasil Belajar

Berdasarkan hasil pretest dilakukan normalitas untuk mengetahui distribusi hasil yangg diperoleh. Berikut ini disajikan uji normalitas masing-masing kelompok.

Tabel 6 Normalitas Data Pretest

\begin{tabular}{|c|c|c|}
\hline Kelas & Chi kuadrat hitung $\chi_{\text {hitung }}^{2}$ & Chi kuadrat tabel $\chi^{2}$ tabel \\
\hline Eksperir & 1,243 & \\
\hline Kontrol & 1,855 & \\
\hline \multicolumn{3}{|c|}{$\begin{array}{l}\text { Pada kelas eksperimen, berdasarkan hasil perhitunan diperoleh } \chi_{\text {hitung }=1,243 \text { dan }} \chi_{\text {tabel }} \\
=7,815 \text { sedangkan pada kelas kontrol diperoleh } \chi_{\text {hitung }=1,855 \text { dan } \chi_{\text {tabel }}=7,815 \text { pada }} \\
\text { taraf signifikan } 5 \% \text {. Berdasarkan kriteria pengujian jika } \chi_{\text {hitung }} \leq \chi_{\text {tabel }} \text { maka distribusi } \\
\text { normal. Dengan demikian hasil pretes kelas eksperimen terdistribusi normal. } \\
\text { Uji homogenitas dilakukan untuk mengetahui apakah kemampuan awal kedua } \\
\text { sampel yan menjadi obyek penelitian bersifat homogen atau tidak. Berdasarkan hasil } \\
\text { penelitian diperoleh sebagai berikut: }\end{array}$} \\
\hline
\end{tabular}

Tabel 7. Uji Homogenitas Pretest

\begin{tabular}{lccc}
\hline \multicolumn{1}{c}{ Kelas } & Rerata & Varians & F $_{\text {hitung }}$ \\
\hline Eksperimen & 36,25 & 68,09 & 1,07 \\
Kontrol & 36,81 & 63,69 & \\
\hline
\end{tabular}

Berdasarkan hasil perhitungan untuk uji homogenitas sampel diperoleh Fhitung $=$ 1,07 dan Ftabel $=2,14$ pada taraf signifikan $5 \%$ berdasarkan kriteriapengujian Fhitung $\leq$ Ftabel maka sampel homogen. Dengan demikian dapat dikatakan bahwa kedua sampel yaitu kelas eksperimen dan kelas kontrol memiliki kemampuan yang homogen.

Dari hasil perhitunga uji-t related untuk sampel berpasangan diperoleh thitung sebesar $t=3,134$ maka dapat disimpulkan bahwa hasil belajar fisika pokok bahasan 
Perubahan Energi yang diajarkan menggunakan media komik lipat sederhana IPA Fisika lebih baik secara signifikan dari pada siswa diajarkan menggunakan metode ceramah yang berarti Ha diterima dan Ho ditolak pada siswa kelas IX MTS Nurul Ishlah Gegelang

Tabel 8. Hasil Uji Hipotesis Posttest

\begin{tabular}{lccccc}
\hline Kelas & Jumlah siswa & Rerata & $\begin{array}{l}\text { Rerata varians } \\
\boldsymbol{s}_{\boldsymbol{t}}^{\mathbf{2}}\end{array}$ & $\mathbf{t}_{\text {hitung }}$ & $\mathbf{t}_{\text {tabel }}$ \\
\hline Eksperimen & 20 & 79,50 & 70,79 & 3,134 & 2,005 \\
Kontrol & 21 & 71,90 & 86,19 & & \\
\hline
\end{tabular}

Berdasarkan hasil perhitungan diperoleh nilai thitung $=3,134$. maka dapat disimpulkan bahwa hasil belajar siswa pada pokok bahasan Perubahan Energi yang diajarkan dengan media komik lipat sederhana IPA Fisika lebih baik dari pada siswa yang diajarkan dengan metode ceramah yang berarti Ha diterima dan Ho ditolak pada siswa kelas IX MTs Nurul Ishlah Gegelang.

\section{SIMPULAN DAN SARAN}

Berdasarkan hasil penelitian diperoleh kemampuan awal siswa untuuk kedua kelompok adalah homogen yang ditunjukkan dengan Fhitung $<$ Ftabel $(1,07<2,14)$ serta perbedaan yang dimiliki antara kedua kelompok tidak signifikan pada pokok bahasan perubahan energi dengan satuan dan pengkuran tes kemampuan akhir yang ditunjukkan dengan thitung $>$ ttabel $(3,134>2,005)$, sehingga Ha diterima artinya ada pengaruh yang signifikan pengajaran dengan menggunaka komik lipat sederhana IPA Fisika lebih efektif meningkatkan hasil belajar Fisika siswa pokok bahasan Perubahan Energi dari pada siswa yang diajarkan dengan metode ceramah pada siswa kelas IX MTs Nurul Ishlah.

Berdasarkan hasil penelitian yang telah dilakukan maka penulis mengajukan beberapa saran antara lain: (1) kepada pihak pengajar, hendaknya mempertimbangkan pengaruh pemberian komik lipaat sederhana IPA Fisika guna meningkatkan hasil belajar; (2) perlu penelitian lebih lanjut dengan pengaruh menggunakan komi lipat sederhana IPA Fisika untuk meningkatan kualitas pendidikan, khususnya pada MTs Nurul Ishlah Gegelang dalam mencapai kualitas tersebut diperlukan metode pengajaran yang efektif dan efesien agar pendidikan ke depannya lebih baik lagi.

\section{E. UCAPAN TERIMA KASIH}

Universitas Muhammadiyah Mataram Yang telah Memberikan Dana stimulus Berupa Dana Hibar Internal Kampus Melalui LPM Universitas Muhammadiyah Mataram.

\section{REFERENSI}

Adriyanto, Dewi Pramita, Abdillah, Syaharuddin, Mahsup, Eka Fitriani. 2019. "Peningkatan Kompetensi Strategis Siswa Melalui Model Pembelajaran Conceptual Understanding Procedures." Justek: Jurnal Sains dan Teknologi 2(1): 01-10. http://journal.ummat.ac.id/index.php/justek/article/view/3535/pdf.

Aribawati, D, F Kristin, and ... 2018. "Penerapan Model Pembelajaran Inkuiri Terbimbing Untuk Meningkatkan Kreativitas Dan Hasil Belajar IPA Siswa Kelas 3 SD.” JUSTEK/ Jurnal Sains \& .... 
Arikunto. 2019. "Metodelogi Penelitian, Suatu Pengantar Pendidikan." In Rineka Cipta, Jakarta, , 21.

Darmayanti, N.W. S., and Linda Sekar Utami. 2018. "Penerapan Metode Latsol (Latihan Soal) Materi Pelajaran Fisika Melalui Kegiatan Bimbingan Belajar Di Luar Jam Sekolah Untuk Mengatasi Kesulitan Belajar Fisika Siswa SMP Di Desa Gontoran, Kecamatan Lingsar, Lombok Barat." SELAPARANG Jurnal Pengabdian Masyarakat Berkemajuan 2(1): 35.

Eka Fitriani, Mahsup. 2018. "Pengaruh Pembelajaran Kooperatif Tipe Jigsaw Untuk Meningkatkan Pemahaman." Justek: Jurnal Sains dan Teknologi 1(2): 01-08. http://journal.ummat.ac.id/index.php/justek/article/view/3541.

Ferniawan, Ferniawan, Johri Sabaryati, and Linda Sekar Utami. 2020. "Efektifitas Penggunaan Media Poster 3 Dimensi Secara Daring Pada Materi Tata Surya Berbasis Google Classroom Untuk Meningkatkan Pemahaman Konsep Fisika Siswa Kelas VII SMPN 1 Wera Tahun Pelajaran 2019/2020." ORBITA: Jurnal Kajian, Inovasi dan Aplikasi Pendidikan Fisika 6(2): 284.

Hamzah, Hamzah, Linda Sekar Utami, and Zulkarnain Zulkarnain. 2019. "Pengembangan Media Pembelajaran Roda Putar Fisika Untuk Meningkatkan Motivasi Belajar Siswa." ORBITA: Jurnal Kajian, Inovasi dan Aplikasi Pendidikan Fisika 5(2): 77.

Ibrahim, Ibrahim, Linda Sekar Utami, and N .W. S. Darmayanti. 2018. "Pengembangan Media Pembelajaran Game Fisika Asik (GASIK) Untuk Meningkatkan Motivasi Belajar Siswa SMP Kelas VIII Materi Pokok Cahaya Dan Sifat- Sifat Cahaya." ORBITA: Jurnal Kajian, Inovasi dan Aplikasi Pendidikan Fisika 4(2): 6.

Kabunggul, Yosua et al. 2020. "Meningkatkan Motivasi Dan Hasil Belajar Siswa Melalui Penerapan Model Pembelajaran Team Game Tournament Berbantuan Media ...." Jurnal Pendidikan Karakter 3(2): 3-6.

Mahsup, and Y. S. Anwar. 2020. "Development of Structured Modules to Improve the Mathematical Understanding of the Circle Concept in Class VIII Mataram 17 Junior High School." In Journal of Physics: Conference Series,.

Mahsup, Mahsup. 2011. "Penerapan Stategi Inquiri Untuk Meningkatkan Hasil Belajar Tentang Sistem Persamaan Linear Dua Variabel.” ßeta 4(2): 120-32. file:///C:/Users/Mahsup/Downloads/document (1).pdf.

-_—. 2018. "Analisis Kesulitan Dalam Memahami Kemampuan Verbal Dalam Membuat Model Matematika Program Linear." Jurnal Ulul Albab 22(2).

Mandailina, Vera, and Mahsup. 2018. "Efektivitas Pembelajaran Matematika Dengan Metode Thinking Aloud Pair Problem Solving (TAPPS) Terhadap Hasil Belajar Siswa Pokok Bahasan Kubus Dan Balok Kelas VIII SMP/MTs." Jurnal Teori dan Aplikasi Matematika (JTAM) 2(2): 144-47.

Marga, Kristina Mudali, M. Isnaini, and Linda Sekar Utami. 2018. "Pengaruh Media Kokami (Kotak Dan Kartu Misterius) Terhadap Keterampilan Berpikir Kritis Dan Motivasi Belajar Siswa Kelas VIII SMP Negeri 19 Mataram Tahun Pelajaran 2017/2018." ORBITA: Jurnal Kajian, Inovasi dan Aplikasi Pendidikan Fisika 4(2): 18.

Mikraj, Abdul, Linda Sekar Utami, and Zulkarnain Zulkarnain. 2019. "Pengaruh Buletin Fisika Berbentuk Buku Saku Untuk Meningkatkan Hasil Belajar Siswa Di MAN 2 Bima Kelas X Materi Hukum Newton Tahun Pelajaran 2018/2019." ORBITA: Jurnal Kajian, Inovasi dan Aplikasi Pendidikan Fisika 5(1): 5.

Muhardini, Sintayana et al. 2020. "Pengembangan Media Pembelajaran Box Nusantara Untuk Membentuk Kemampuan Memahami Konsep Tematik Pada Siswa Sekolah Dasar." Jurnal Kependidikan: Jurnal Hasil Penelitian dan Kajian Kepustakaan di Bidang Pendidikan, Pengajaran dan Pembelajaran 6(2): 284. 
Mukminah, Eka Fitriani, Mahsup, Syaharuddin. 2019. "Efektifitas Model Pembelajaran Kooperatif Tipe Teams Games Tournament Untuk Meningkatkan Hasil Belajar." Justek: Jurnal Sains dan Teknologi 2(2): 1-5. http://journal.ummat.ac.id/index.php/justek/article/view/3533.

Murtiah, B. 2018. "Penerapan Pendekatan Kontekstual Menggunakan Media Gambar Binatang Untuk Meningkatkan Keterampilan Mendeskripsi Secara ...." JUSTEK/ Jurnal Sains \& Teknologi.

Nurfiati, Vera Mandailina, Mahsup, Syaharuddin, Abdillah. 2020. "Effect of Make A Match Learning Model on Student Learning Outcomes on Statistical Materials." Justek: $\begin{array}{lllll}\text { Jurnal Sains dan } & \text { Teknologi } & \text { 1-8. }\end{array}$ http://journal.ummat.ac.id/index.php/justek/article/view/3509.

Rahmatin, Nutia, Dewi Pramita, Sirajuddin Sirajuddin, and Mahsup Mahsup. 2019. "Pengembangan Modul Pembelajaran Bangun Ruang Dengan Metode Creative Problem Solving (CPS) Pada Siswa Kelas VIII SMP." JTAM / Jurnal Teori dan Aplikasi Matematika 3(1): 27.

Setyowati, Endah, Firosalia Kristin, and Indri Anugraheni. 2018. "Penggunaan Model Pembelajaran Discovery Learning Untuk Meningkatkan Kreativitas Dan Hasil Belajar Siswa Kelas 5 SD Negeri Mangunsari 07." JUSTEK/ Jurnal Sains \& Teknologi 1(1): 76-81.

Sugiyono. 2013. "Buku - Sugiyono." In Metode Penelitian Kuantitatif, Kualitatif, Dan R \& $D, 407$.

Utami, Linda Sekar. 2018. "Perbandingan Analisis Numerik Menggunakan Metode Secant dan Metode Iterasi Satu Titik Untuk Menentukan Koefisien Gesek Udara Pada Kubus Dan Silindris." Paedagoria / FKIP UMMat 5(2): 43.

Utami, Linda Sekar, and N.W.S Darmayanti. 2019. "Efektifitas Pembelajaran Multirepresentasi Untuk Meningkatkan Pemahaman Konsep Mahasiswa Fisika Materi Gelombang Dan Optik Tahun Akademik 2018/2019." ORBITA: Jurnal Kajian, Inovasi dan Aplikasi Pendidikan Fisika 5(1): 53. 